\title{
The role of Russian volunteers in the collapse of the international legion in the South African War
}

\author{
Boris Gorelik \\ Institute for African Studies, Russian Academy of Sciences, Moscow ${ }^{136}$
}

\begin{abstract}
The establishment of an international legion by General Georges de Villebois-Mareuil in March 1900 was the most ambitious attempt to coordinate the activities of foreign volunteer units within a single formation during the South African War. On the general's death (5 April 1900), De Villebois's Russian deputy and successor, Lieutenant Colonel Yevgeny Maximov, lost control of the legion. As a hierarchical formation, it survived De Villebois by only two weeks. Given Maximov's ample experience in conventional and unconventional warfare, and the accolades that he later won from the republican political and military leadership, including the rank of general, the legionnaires' opposition to him appears to be unjustified. Accounting for the discrepancy between historians' perceptions of Maximov and his lack of success in controlling the legion is based on a premise that legionnaires had compelling reasons to reject his authority. Maximov had come to Africa ostensibly as a journalist. He was yet to earn the respect of his subordinates because he had not seen action in the South African War. In subsequent weeks, having resigned from his post in the legion, he distinguished himself in the engagement at Tobaberg as the leader of the Dutch corps. By then, Maximov had the 'moral authority' to command an international unit, but his poor health prevented him from carrying on fighting. Unlike De Villebois, who was supported by like-minded French lieutenants, Maximov could not rely on his compatriots. Instead of endorsing his claim to leadership, the Russian corps refused to join the legion while he was in charge, and intentionally discredited him. In the power vacuum after De Villebois's death, the legion collapsed, and a chance to transform the emerging alliance of foreign volunteer units into a formidable force was missed.
\end{abstract}

\section{The ill-starred successor}

In March 1900, with the burgher troops retreating on several fronts, the republican military leadership decided to assemble volunteers of various nationalities fighting on the Boer side. The establishment of an international legion by General Georges de Villebois-Mareuil, the most senior European officer on the side of the Boers, was the most ambitious attempt to coordinate the activities of foreign volunteer units within a single formation during the South African War. ${ }^{137}$

On 5 April, the general fell in battle when his detachment was overwhelmed by Lieutenant General PS Methuen's troops near Boshof. The legion as a hierarchical formation survived De Villebois by only two weeks. Afterwards, it functioned as a loose association of autonomous units. 
The demise of the legion has been viewed by historians as a consequence of the general's death. A biographer of Camillo Ricchiardi, an Italian volunteer on the Boer side, opines that only De Villebois had "the capacity and charisma required to have kept such a complex and divergent unit going". ${ }^{138}$ Nobody else could hold together this alliance of fiercely independent and ill-disciplined combatants. ${ }^{139}$

Why not De Villebois's deputy, Lieutenant Colonel Yevgeny Maximov (1849-1904)? One of the most senior foreign officers on the Boer side, Maximov had ample experience in conventional and unconventional warfare. He became the second foreigner after De Villebois to receive the rank of general in the burgher armies. Reportedly, General Louis Botha referred to the Russian officer as "the bravest man in the Transvaal and a gifted leader". ${ }^{140}$ President Paul Kruger believed that Maximov's services to the ZAR "were of extraordinary importance and deserving of great respect". ${ }^{141}$ State Secretary Francis William Reitz recounted that Boer commandos praised Maximov's "bravery, his ability to keep discipline among his men and the value of his advice". ${ }^{142}$

However, despite the trust placed in him by De Villebois and the support from the republican political leadership, this valiant soldier and gifted commander failed as the French general's replacement. In less than a week after his appointment, Maximov gave up the command of the legion. He could not overcome what Michael Davitt, an Irish politician and war correspondent on the Boer side, characterised as "jealousies breaking out among the numerous would-be successors of the gallant French officer". ${ }^{143}$

Given Maximov's abilities and experience, the volunteers' opposition to him appears to be unjustified. His short temper and disciplinarianism put his subordinates off. However, agreeableness is not a prerequisite for leading a military unit, and the commander's idiosyncrasies were eclipsed by his glory. It would also be an exaggeration to assert that leaders of volunteer units preferred to keep their independence at all costs, because soon after the collapse of the legion, they petitioned the authorities for its revival. Davidson and Filatova, in their seminal study of Russian involvement in the South African War, suggest that legionnaires found it hard to emulate Maximov's self-sacrifice in battle. ${ }^{144}$ Yet, while few combatants risked their lives as readily as he did, Maximov got a chance to show his bravery on South African soil only after he had lost control over the legion.

What accounts for the discrepancy between historians' perceptions of Maximov as an outstanding military leader and his lack of success in controlling the legion?

Legionnaires did not have the benefit of hindsight, which influences our current perceptions of Maximov. Perhaps their view was affected by important considerations that may have been overlooked or underplayed in historiography. I agree with Davidson and Filatova who believe that legionnaires mistrusted Maximov. ${ }^{145}$ I hypothesise that his position in the legion was precarious from the beginning, and that his subordinates had compelling reasons to reject his authority. The power vacuum led to the collapse of the international legion.

The study on which this article reports involved re-examination of primary sources used by my predecessors, particularly accounts by legionnaires and observers. The 
narratives were analysed in the context of Maximov's military career from the 1870 s to establish his status in South Africa before and after joining the legion. Understanding the legionnaires' opposition to Maximov also required a scrutiny of the often-quoted book by Sophia Izedinova, a Russian nurse with the Russo-Dutch Ambulance and the most dedicated chronicler of Maximov's career in South Africa. ${ }^{146}$ Her memoir is regarded as a key primary source of information on the international legion although her partiality for Maximov and the inordinateness of her criticism of other foreign volunteers have been recognised by historians.

\section{A critique of Izedinova's account as a primary source}

"As far as her admiration for Maximov is concerned, her memoirs leave little doubt that the nurse was in love with him", note Davidson and Filatova. ${ }^{147}$ Izedinova's bias in favour of the Russian officer does not invalidate her account. Nevertheless, it brings into question her assessment of those who displeased Maximov, including Boer generals and leaders of foreign volunteer units that stayed clear of the ill-fated legion.

Izedinova tended to range Maximov against other commandants by emphasising his valour and integrity and their supposed egoism and ineptitude. For example, a biographer of De Villebois notes that her opinion of the French general as tactless and maladroit disagreed with statements by those who, unlike the nurse, knew the founder of the legion personally. ${ }^{148}$ Izedinova alleged that the Italian scouts were plunderers although their unit did not operate at Fourteen Streams, the only area where Izedinova worked on the frontline. ${ }^{149}$ She stated that Alexey Ganetsky, the commandant of the Russian corps, brought his country into disrepute, although other accounts indicate that Izedinova was prejudiced because he prevented Maximov from leading that unit. ${ }^{150}$

Tracing the nurse's career in March and April 1900 reveals that she did not witness either the formation and disintegration of the legion or the engagements in which Maximov took part and which she vividly described in her book.

The nurse arrived in Kroonstad with the Russo-Dutch Ambulance in late March 1900. She spent most of her time at the hospital, where her only source of information on the legion was "rumours and stories from both patients [...] and our frequent visitors, Dutch military agents". ${ }^{151}$ Soon, while the legion was still being formed, Izedinova left the town for Fourteen Streams, and never returned to the Orange Free State. ${ }^{152}$ Working nearly $300 \mathrm{~km}$ from Kroonstad in the following four weeks, she had no first-hand knowledge of the tensions within the international legion.

Like other Russians, Izedinova distrusted Maximov and spoke to him politely but coldly until she learnt about his gallantry. ${ }^{153}$ In mid-May, she made friends with the convalescent compatriot and, apparently, travelled back to Russia in his company.

When writing about the war, other Russian doctors and nurses focused on their medical work. They were mostly interested in wounds and their treatment, the recovery of their patients, and the attitudes of their colleagues and the authorities. Even Izedinova's superiors in the Russo-Dutch Ambulance rarely discussed political and military matters 
in their reports, articles and interviews. "We have had little accurate information regarding the course of hostilities, because most rumours that reach us turn out to be false," admitted a Russian doctor in April 1900. ${ }^{154}$

By contrast, Izedinova dedicated dozens of pages to her descriptions of battles; characterisation of burgher leaders and foreign volunteers; evaluation of Boer foreign relations and military organisation; assessment of Boer strategic plans and their implementation; and explanation of causes for Boer defeats. If her book is viewed as a memoir, the dogmatism of her views of people that she hardly knew and the amount of detail in her stories of events that she did not witness, can be puzzling.

The book came out in 1903, when first-hand accounts of the war had already been published, including the De Villebois journal. The nurse cited those works, but she also claimed to have collected "accurate, reliable" data in her conversations with the Reitz family, General Louis Botha's wife and other Boers. ${ }^{155}$ Yet, with regard to the international legion, it seems that her main source of information was Yevgeny Maximov. Some passages in her account of the legion carry strong emotion, although the nurse, unlike Maximov, did not have a vested interest in its success. For example, she fully shared Maximov's opinion of De Villebois, which the Russian officer expressed in his writings. Apparently, the nurse's interpretation of the events was heavily influenced by the Russian officer's stance, which made her account unobjective. Moreover, she probably conveyed some of his views and judgements that he was unable or reluctant to publish under his name.

Izedinova did not state clearly that her views of the legion were based on indirect knowledge of the situation. In this respect, her book is not a memoir but a secondary source, grounded on unidentified accounts. Therefore, I have used her statements with caution and tended to rely on other sources.

\section{The commandant's deputy}

During the conventional and transitional phases of the war, foreigners who fought for the republican cause either joined burgher commandos or organised independent, relatively small units which hardly collaborated with one another and reported directly to the commander-in-chief. ${ }^{156}$

"Some of the leaders of those units asked commandants of the nearest commandos for instructions, but they could rarely get the necessary information and instructions even from them", recounted the Russian military attaché with the Boer troops. "Consequently, those who considered themselves scouts carried out reconnaissance on their own initiative, completely disregarding the requirements of the situation; therefore, the information that they delivered was rarely useful, and the Transvaal generals did not always trust it." 157

The decision to form an international legion under De Villebois was made at the historic council of war in Kroonstad on 17 March 1900, when the younger military leaders insisting on bolder action, better mobility and stricter discipline gained the upper 
hand. De Villebois called it the "European legion" (la légion européenne), although membership was open to men from North America too. ${ }^{158}$ Boer political and military leaders exerted their influence to swell the ranks of the new formation. Encouraged by President Martinus Theunis Steyn, a strong proponent of the legion, the government of the Orange Free State offered economic incentives to the legionnaires. ${ }^{159}$ Foreign volunteers started gathering in Kroonstad, the temporary capital of the republic.

Newly appointed as Boer general and inspired by his service in the French Foreign Legion, De Villebois believed that control over volunteer units had to be exerted by professional soldiers who were familiar with best practice in Western-style warfare; therefore, his staff was composed of European and American officers. ${ }^{160}$ Maximov, a European-trained soldier, shared his exasperation at the tactical errors of the Boers and their reluctance to assault the enemy when fortune would favour it. When Maximov first met De Villebois in Kroonstad on 23 March 1900, the general invited him to be his second-in-command.

Three decades before, as a cavalry officer in the peacetime Russia seeking a baptism of fire, Maximov had resigned and fought against Turkey in the Herzegovina uprising of 1875. He commanded volunteer units in the Serbian-Turkish War (1876-1877). Russia intervened in the hostilities, and Maximov re-joined the army. However, he was appointed military superintendent of railway stations, and spent the Russo-Turkish War (1877-1878) in the rear. Aspiring to see action again, Maximov went to Central Asia with a Red Cross ambulance and attained distinction in the Russian conquest of Turkestan in charge of a flying column in 1880-1881. The lieutenant colonel travelled in Ethiopia and Asia as a journalist and nearly went to Crete to fight as a volunteer for the Greeks against the Ottoman forces in 1896, but a conflict was avoided. ${ }^{161}$

De Villebois wanted his legion to conduct cavalry raids, similar to the ones carried out in the American Civil War, and it was expected that Maximov's experience in guerrilla warfare and commanding a flying column would prove useful. Being well-connected, Maximov could also help De Villebois to deal with the Boer authorities. Besides, as the French volunteer, Henri-Marie-Albert Lecoy de la Marche pointed out, the lieutenant colonel was chosen as De Villebois's chief of staff "perhaps because of his nationality". ${ }^{162}$ De Villebois had written a monograph on the Imperial Russian Army. ${ }^{163}$

Maximov accepted the proposal; the new position matched his ambition and experience. Soon, he procured from the authorities the ammunition that they had promised to De Villebois. Meanwhile, the founder of the legion, eager to take the field again, had no time for organisational problems. On 24 March 1900, De Villebois left Kroonstad with a flying column comprising dozens of foreign volunteers to make raids in the direction of Kimberley. As his deputy, Maximov was to complete the formation of the legion and wait for an order to follow De Villebois with the rest of the men. ${ }^{164}$

\section{The defiant Russian corps}

Among the volunteer units that came to Kroonstad to join the legion was the 25-30-strong Russian corps. Formed in Natal in mid-March, the unit consisted of Russian-speaking members as well as Italians, Germans, Greeks and Portuguese. 
The commandant of the Russian corps, Second Captain (stabs-rotmistr) Alexey Ganetsky, had charisma but none of Maximov's combat experience. A son of an illustrious general, Ganetsky left active duty as a dragoon officer with a Guards regiment to become an assistant to the minister of war. This 'well-known personage' in Russian society married a rich divorcee, and rebuilt the luxurious Sandunovsky Baths in Moscow. ${ }^{165}$

On the ship to Mozambique in February 1900, Ganetsky discussed the idea of a Russian unit with Maximov and seemed willing to be his lieutenant. On their arrival, while the senior officer was establishing contact with political leaders of the ZAR in Pretoria, Ganetsky travelled to Glencoe. In early March, at the camp near the headquarters of the republican forces, he recruited Russian volunteers for the new corps. As the originator of the idea to form the unit, the charming and enthusiastic Ganetsky was elected to be commandant. Even those who had fought on Spioenkop and Thukela Heights supported the nomination of this newcomer.

When Ganetsky returned to Pretoria as the leader of the Russian corps, Maximov felt cheated. The lieutenant colonel believed that he deserved to be their commandant far more than the "trickster" (mazourik), as he called Ganetsky in his diary. ${ }^{166}$ During their confrontation, Ganetsky, supported by other members of the corps, refused to renounce his claim to leadership.

It may seem extraordinary that the Russian officers disregarded military rank preferring to obey a second captain rather than a lieutenant colonel whose military career spanned 30 years. They did not respect the man who had brought honour to himself in charge of similar units in major wars. According to a member of the corps, Second Lieutenant Yevgeny Avgustus, they did not believe that Maximov was qualified "to set an example of proper organisation for the Boers" 167 even though they detested the lack of discipline and other flaws of burgher commandos.

Neither Ganetsky nor Maximov had proved their abilities in that war; they had not yet participated in engagements with the British, and their military credentials could not be verified in the Boer republics. However, members of the Russian corps took Ganetsky at his word. Their distrust of Maximov should be attributed to other factors.

In South Africa, Maximov was known only as a journalist and marksman who once shot a running springbok from the window of a moving train. For weeks after his arrival, Maximov introduced himself as a war correspondent for Russian newspapers, although his travel expenses were met by the Ministry of War in Saint Petersburg. Before his departure, the Russian General Staff had asked the Ministry of Foreign Affairs to introduce Maximov to the ZAR ${ }^{168}$ government. Davidson and Filatova suggest that the Russian government wanted Maximov to advise the Boer authorities on the Russian foreign policy. ${ }^{169}$ In early March, almost simultaneously with the secret discussions in Europe on a Russo-French-German mediation between the warring parties, Maximov convinced President Steyn to approach the Russian tsar with a request for conciliation. Perhaps his conversations in Pretoria had an effect, because, on 10 March 1900, Steyn and Kruger asked the great powers for their good offices to resolve the military conflict in South Africa. ${ }^{170}$ 
Although the Boer presidents and other important politicians readily discussed politics and foreign relations with Maximov, his offer of assistance in military matters was declined. When he tried to organise a unit under his command, the republican authorities did not support his efforts. In frustration, Maximov was about to join a burgher commando as rank and file when he received the offer from De Villebois. ${ }^{171}$

Moreover, his compatriots in the Russian corps considered him an impostor: a policeman pretending to be a soldier. They knew that Maximov had served in the Special Corps of Gendarmes, the uniformed security police of the Imperial Russian Army; it was during those three years that he was made lieutenant colonel. ${ }^{172}$ Members of the Russian unit alleged that Maximov spied on his compatriots for their government. As reported by a Russian military agent who interviewed Russian volunteers on the Boer side, the lieutenant colonel appeared to be excessively involved in political affairs for a soldier. ${ }^{173}$ His personal relations with top-ranking officials of the Boer republics strengthened the volunteers' conviction that he had a secret mission. ${ }^{174}$ The Russian corps resented the prospect of being commanded by an "undercover agent". ${ }^{175}$

Their suspicion was groundless: Maximov had resigned from the security police sixteen years before the South African War, and nothing suggests that he was their agent afterwards. ${ }^{176}$ However, the Russian corps did not conceal their low opinion of the lieutenant colonel. A French volunteer recounted that the Russians could not pardon Maximov's "position as a police officer and even professed a certain contempt for him". ${ }^{177}$

By the time the Russian corps reached Kroonstad in late March 1900, De Villebois had departed, and Maximov assumed command of the remaining part of the legion. Ganetsky and his subordinates had not changed their minds about Maximov, especially now that his position was far more powerful than the one that he had sought from them. Unwilling to follow the lieutenant colonel's orders, the Russian corps refused to join the international legion.

Their disrespect was imparted to other foreign volunteers bolstering opposition to De Villebois's deputy. The Russians spread rumours about Maximov, which he was unable to dispel, having no one to vouch for him. When the Russians revealed that Maximov had been a police officer, it reinforced the prejudice against him in the legion.

The fact that Maximov had once served in law enforcement in Russia could not, by itself, compromise him in the eyes of legionnaires. Professional soldiers were in the minority among foreign volunteers. Their overseas ranks and service records mattered little on commando, and they had to earn their reputations anew on South African battlefields. Besides, it was known that a foreign-born policeman, Major Gerard Marie Johan van Dam (1855-1940), was in charge of the prominent Johannesburg Police Commando. However, those who viewed Maximov as an unnecessary intermediary between themselves and De Villebois, particularly commandants of volunteer units within the legion, had no interest in rebutting the allegations against him. ${ }^{178}$ 
In anticipation of news from De Villebois, the Russian corps put itself at the disposal of General Philip Botha, south of Brandfort. Lieutenant Ernest Galopaud and the French volunteers under his command also defied Maximov, leaving for Hoopstad in search of De Villebois and his flying column. About eighty Dutch volunteers as well as the German corps under Captain Charles Lorenz, the French unit under Lieutenant Olivier d'Etchegoyen and the Austro-Hungarian corps under Captain Julius Illés remained in Maximov's charge. However, the lieutenant colonel struggled to keep order among his subordinates or even to have them live in the camp and report for duty. ${ }^{179}$ The inaction and anxiousness in De Villebois's absence exacerbated ethnic conflicts among the Dutch, the French and the German volunteers; therefore, Maximov redeployed his legionnaires from Kroonstad to Brandfort. ${ }^{180}$

\section{The collapse and attempts at revival}

The death of De Villebois and the surrender of his men, which represented at least a third of the legion, in the Battle of Boshof shocked foreign volunteers at Brandfort. ${ }^{181}$ The British interred De Villebois with military honours, and he was mourned as a hero on the republican side. The most prominent foreign volunteer, on whom both legionnaires and Boer leaders pinned their hopes, seemed irreplaceable.

The news of the general's death reached his men at Brandfort on 7 or 8 April $1900 .{ }^{182}$ Maximov succeeded De Villebois as commandant of the legion, having been appointed by the president of the Orange Free State. Nevertheless, most legionnaires did not recognise his leadership. Neither was he able to resolve the disputes among his subordinates. ${ }^{183}$

Besides, Maximov had a quarrel with Captain Lorenz, commandant of the German corps, whom he had characterised as "dutiful" and "soldier-like" (obyazatelen, pokhozh na soldata) in his diary not long before. ${ }^{184}$ The German captain had been confident that the legion would grow to be a stable and efficient formation, but apparently, Maximov saw him as a contender. The Russian officer accused Lorenz of unscrupulousness in commissariat arrangements and tried to replace him. The Germans stood up for their elected leader, causing the Russian commandant to expel them from the legion. ${ }^{185}$ Several compatriots of Lorenz crossed over to the German unit under Richard Runck. The indignant Maximov complained to President Steyn, but there was no bringing them back. ${ }^{186}$

The Russian officer remained commandant of the international legion for only a few days. Since no other foreigner had the backing of most volunteers, Maximov was superseded by a Boer officer, General De la Rey's brother, Adriaan. However, by 13 April, when the new leader was appointed, the legion had practically broken up. The volunteer units regarded De la Rey as "honorary commandant", and his authority was nominal. ${ }^{187}$

Maximov retained control only of the Dutch corps, which was, judging by a contemporary photograph, comparable to the Russian unit in size (just over thirty men). ${ }^{188}$ The corps operated in coordination with General WJ Kolbe's commandos. However, Maximov did not inspire unswerving loyalty among his men. Most of them were dissatisfied with 
his strict ways, as he was trying to organise basic field training and ensure hygiene in the camp. They were especially annoyed by Maximov's reluctance to allow them to mix with other volunteers who could, in his opinion, undermine their esprit de corps. However, the Dutch bore with Maximov for fear of a split within their unit. ${ }^{189}$

To the reader of Izedinova's account, it may seem as if Maximov established firm discipline in the Dutch corps. Yet, the memoir of his subordinate indicates that the nurse, or her informants, indulged in wishful thinking. "There was not much order in the camp," recounted Cornelis Plokhooy, a former member of the Dutch corps, "it was a gang of real daredevils - a fighting unit". ${ }^{190}$ When they did not fight the enemy, they fought among themselves. The commandant's efforts to keep discipline were largely foiled. The men often quarrelled with Maximov over his attempts to treat them as "Cossacks", whom he admired. Allegedly, the Dutch corps engaged in looting on both sides of the frontline while Maximov shut his eyes to it if they shared their 'booty' (buit) with him. ${ }^{191}$ His corps was typical of volunteer units in that war, with their insubordination and flexible hierarchies.

At the end of April, Maximov had a chance to display his leadership and courage in a serious engagement. He sustained severe wounds when the Dutch corps under his command held the Tobaberg Hill, defending the road to the burgher position at Houtnek. Vastly outnumbered, the commandant and his men repulsed British charges for a day until they were ordered to retreat. ${ }^{192}$ This was the highlight of the Russian officer's twomonth career with the Boer forces. Several commandos elected him as general. Yet, it was his last battle on the republican side: his shoulder blade was splintered and his skull was damaged by a bullet. Being no longer fit for active service because of his injuries at Tobaberg, Maximov relinquished command of his unit and returned to Russia for recuperation.

New attempts to centralise control over volunteer units began in May 1900. Former lieutenants of De Villebois, such as D'Etchegoyen, Illés, Lorenz and Wrangel, initiated this movement. Commandant Johan Samuel Frederik Blignaut (1867-1901) agreed to take charge of the relaunched legion. At first, Boer political leaders, including the State Secretary of the ZAR, supported this enterprise, even threatening dissidents with punishment under martial law. The foreigners who had served in the field were ordered to register with the office of the 'Uitlanders corps' in Pretoria. However, after Louis Botha had turned the plan down, the official support was withdrawn, and the legion disbanded. ${ }^{193}$ Blignaut assumed the command of the Dutch corps, which was reconstituted as an independent unit once it became clear that the 'Uitlanders corps' would not materialise. ${ }^{194}$

The idea of an international formation was explored again during the guerrilla phase of the war. In June 1900, the leader of the Italian Scouts as one of General Louis Botha's troops, Captain Camillo Ricchiardi, commanded a "foreign legion" comprising volunteer units in $1901 .{ }^{195}$ It was far smaller than De Villebois's legion, because most foreign volunteers had already left South Africa. 


\section{Conclusion}

The most plausible explanation of Maximov's fiasco is that legionnaires did not see him as an inspirational leader. This version was put forward by French subordinates of De Villebois, who regarded him as "the soul of the legion". ${ }^{196}$ They argued that Maximov did not have the "moral authority" (autorité morale), which members of the international legion had accorded to the general. ${ }^{197}$

De Villebois, a retired French colonel and veteran of European and colonial wars, had come to the Transvaal as a soldier to fight against the British. He was introduced in this capacity to prominent Boer generals and advised them before important battles. De Villebois became the first foreigner to be given the rank of general in the republican armies. Although the burgher military leaders often ignored his recommendations, partly because he harshly criticised their tactics, they valued his experience. When he familiarised himself with the local methods of warfare, the Boer governments allowed him to form the international legion in the worsening military situation. ${ }^{198}$

Viewed by some as a quixotic figure, the French founder was nevertheless trusted by foreign volunteers and their commandants. After his heroic death, he was esteemed. A contemporary Dutch historian of the South African War pointed out that the death of De Villebois was perceived by those who had placed themselves under his orders as an irreparable loss, because no one else seemed to have "the ability to lead such a legion, uniting the different nationalities under one banner". ${ }^{199}$

Maximov was among De Villebois's critics. In his diary, he characterised the general as "inept" (neoumeliy) and promised to "put things to rights" in the legion. ${ }^{200}$ The Russian lieutenant colonel, whose credibility rested on the general's confidence, did not realise the precariousness of his own position. Maximov had come to Africa ostensibly as a journalist, not as a professional soldier. Boer politicians valued his opinion, regarding him as an emissary of the Russian government; civilians, not military leaders, appointed him as De Villebois's successor. Without combat experience in the South African War, Maximov was yet to earn the respect of Boer soldiers and his own subordinates. Only in subsequent weeks, having resigned from his post in the legion, did he make daring raids behind the enemy lines with his Dutch corps and distinguished himself in the engagement at Tobaberg. Afterwards, Maximov already had the 'moral authority' to command an international unit, but his poor health prevented him from fighting on.

Unlike De Villebois, who was supported by like-minded French lieutenants, Maximov could not rely on his compatriots. Instead of endorsing his claim to leadership, the Russian corps refused to join the legion while De Villebois was in charge and intentionally discredited him. The slanderous rumours that they circulated set other volunteers against De Villebois's deputy. Their unwillingness to serve under the lieutenant colonel caused legionnaires to misjudge him and challenge his mandate. No other officer among them had their overwhelming support either. Meanwhile, the Boers did not undertake on the strenuous task of rallying and organising foreign volunteers either. A chance to transform the emerging alliance of foreign volunteer units into a formidable force was missed. 


\section{ENDNOTES}

${ }^{136}$ Gorelik specialises in the history of Russian-South African encounters and Russian perceptions of South Africa. His works include 'An Entirely Different World': Russian Visitors to the Cape 1797-1870 (Van Riebeeck Society, 2015) and the South African Military History Society publication of Yevgeny Avgustus's memoir, A Russian Fighting for the Boer Cause (2016). Contact the author at boris.gorelik@inafr.ru

${ }^{137}$ F Pretorius. "Welcome but not that welcome: The relations between foreign volunteers and the Boers in the Anglo-Boer War of 1899-1902". In CG Krüger \& S Levsen (eds), War volunteering in modern times. London: Palgrave Macmillan, 2010, 127.

${ }^{138}$ M Lupini. Camillo Ricchiardi: Italian Boer War hero. Melville: Scripta Africana, 1988, 75.

${ }^{139}$ B Pottinger. The foreign volunteers: They fought for the Boers (1899-1902). Melville: Scripta Africana, 1986, 231.

${ }^{140}$ Quoted in A Davidson \& I Filatova. The Russians and the Anglo-Boer War, 1899-1902. Cape Town: Human \& Rousseau, 1998, 17.

${ }^{141}$ Ibid., p. 80.

${ }^{142}$ SV Izedinova. Neskolsko mesyatsev u burov: vospominaniya sestry miloserdiya [A few months with the Boers: A nurse's memoir]. Saint Petersburg: Tipografiya AS Souvorina, 1903, 283. (Translated from Russian). Also available in English: SA Izedinova. A few months with the Boers: The war reminiscences of a Russian nursing sister (C Moody, trans, ed). Johannesburg: Perskor, 1977.

${ }^{143}$ M Davitt. The Boer fight for freedom. New York: Funk \& Wagnalls, 1902, 334-335.

${ }^{144}$ Davidson \& Filatova op. cit., pp. 75, 82-83.

${ }^{145}$ Ibid., p. 83.

${ }^{146}$ Izedinova op. cit.

${ }^{147}$ Davidson \& Filatova op. cit., p. 82.

${ }^{148}$ RM Macnab. The French colonel: Villebois-Mareuil and the Boers, 1899-1900. Cape Town: Oxford University Press, 1975, 180.

${ }^{149}$ Lupini op. cit., p. 76.

${ }^{150}$ For a comprehensive account of the unit's history and their conflict with Maximov, see B Gorelik. "The Russian Corps in the Anglo-Boer War: Two months of misfortune". Military History Journal 2020. 19/1. 10-17.

${ }^{151}$ Izedinova op. cit., p. 176. (Translated from Russian)

152 Ibid., pp. 205, 207.

${ }^{153}$ Ibid., p. 124.

${ }^{154}$ V G Shubin, N G Voropayeva, R Vyatkina, V Khritinin, I Liebenberg (eds). Anglo-burskaya voina 1899-1902 godov glazami rossiyskih poddannyh [The Anglo-Boer War of 18991902 as seen by Russian subjects]. Vol 9. Moscow: Izdatel I B Belyi, 2012. 143.

${ }^{155}$ Izedinova op. cit., p. 111.

${ }^{156}$ F Pretorius. "The Second Anglo-Boer War: An overview". Scientia Militaria 30/2. 2000. 111.

${ }^{157}$ V Romeyko-Gurko. Voyna Anglii s Yuzhno-Afrikanskimi respublikami 1899-1901 gg. [The War of England against the South African republics, 1899-1901]. Saint Petersburg: Voyenno-Uchetny Komitet Generalnogo Shtaba, 1901, 67. (Translated from Russian)

${ }^{158} \mathrm{G}$ Villebois-Mareuil. "Instruction pour la formation de la légion européenne" [Instructions for the formation of the European legion]. 23 March 1900. Reproduced in A Vinogradsky. Anglo-burskaya voina v Yuzhnoy Afrike [The Anglo-Boer War in South Africa]. Vol 2. Saint Petersburg: Ekonomicheskaya Tipo-litografiya, 1902, unnumbered pages.

${ }^{159}$ Izedinova op. cit., p. 209. 
${ }^{160}$ Davitt op. cit., pp. 306-307; O D'Etchegoyen. Ten months in the field with the Boers: By an ex-lieutenant of General De Villebois-Mareuil. London: William Heinemann, London, 1901, 113; W van Everdingen. De oorlog in Zuid-Afrika: Tweede tijdvak [The War in South Africa: Second period]. Vol 1. Delft: J Waltman Jr, 1905, 146-147.

${ }^{161}$ V G Shubin et al. Anglo-burskaya voina 1899-1902 ... Vol 6, pp. 64-72, 80; Y Avgustus. "Vospominaniya uchastnika anglo-burskoy voyny 1899-1900 gg." [A combat memoir of the Anglo-Boer War 1899-1900]. Varshavsky Voyenny Zhurnal 1. 1902. 25.

${ }^{162}$ H-M-A Lecoy de la Marche. Souvenirs de la guerre du Transvaal: journal d'un volontaire (mars-septembre 1900) [Memoirs of the Transvaal War: A volunteer's diary (MarchSeptember 1900]. Paris: A Colin, 1901, 25-26. (Translated from French)

${ }^{163} \mathrm{G}$ de Villebois-Mareuil. L'armée russe et ses chefs en 1888 [The Russian Army and Its Leaders in 1888]. Paris: Librairie moderne, 1888.

${ }^{164}$ Davitt op. cit., pp. 306-307; D’Etchegoyen op. cit., p. 115; Macnab op. cit., p. 180.

165 "Russian Boer officers". Daily Mail. 23 November 1899. 4. V G Shubin et al. Anglo-burskaya voina 1899-1902 _.. Vol 8, pp. 16, 281; "Otyezd v Transvaal" [Departure for the Transvaal]. Peterburgskaya Gazeta. 19 December 1899; "Paris day by day". The Daily Telegraph, 9 November 1899. 11.

${ }^{166}$ V G Shubin et al. Anglo-burskaya voyna 1899-1902 _... Vol 6, p. 11.

${ }^{167}$ Y Avgustus. "Vospominaniya uchastnika anglo-burskoy voyny 1899-1900 gg." Varshavsky Voyenny Zhurnal 9. 1901. 889. (Translated from Russian)

168 Zuid-Afrikaansche Republiek (South African Republic)

${ }^{169}$ Davidson \& Filatova op. cit., pp. 85-86.

${ }^{170}$ D Spring. "Russian foreign policy and the Boer War". In K Wilson (ed), The international impact of the Boer War. Abingdon: Routledge, 2014, 56-57; V G Shubin et al. Angloburskaya voyna 1899-1902 ... Vol 6, pp. 7-10.

${ }^{171}$ V G Shubin et al. Anglo-burskaya voyna 1899-1902 ... Vol 6, p. 3.

${ }^{172}$ NG Voropayeva, RR Vyatkina \& GV Shubin (comp). Anglo-burskaya voina, 1899-1902 gg.: Po arkhivnim materialam i vospominaniyam ochevidtsev [Anglo-Boer War, 1899-1902: Memoirs and archival materials]. Moscow: Vostochnaya Literatura, 2001, 514; Y Avgustus. "Vospominaniya uchastnika anglo-burskoy voyny 1899-1900 gg." Varshavsky Voyenny Zhurnal 1. 1902. 22.

${ }^{173}$ V G Shubin et al. Anglo-burskaya voina 1899-1902 _.. Vol 8, p. 281.

${ }^{174}$ Y Avgustus. "Vospominaniya uchastnika anglo-burskoy voyny 1899-1900 gg." Varshavsky Voyenny Zhurnal 6. 1902. 554.

${ }^{175}$ Ibid.

${ }^{176}$ Y Avgustus. "Vospominaniya uchastnika anglo-burskoy voyny 1899-1900 gg." Varshavsky Voyenny Zhurnal 1. 1902. 22; Voropayeva et al. op. cit., p. 514.

${ }^{177}$ Lecoy de la Marche op. cit., pp. 25-26. (Translated from French)

${ }^{178}$ Davitt op. cit., pp. 334-335; Lecoy de la Marche op. cit., pp. 25-26.

${ }^{179}$ Izedinova op. cit., p. 207.

180 "Une entrevue avec le Colonel Maximof" [An interview with Colonel Maximof]. Le Temps. 31 July 1902. 2 .

${ }^{181}$ D'Etchegoyen op. cit., p. 120.

${ }^{182}$ Ibid.; R Raoul-Duval. Au Transvaal et dans le Sud-Africain avec les attachés militaires [In the Transvaal and South Africa with military attaches]. Paris: C Delagrave, 1902, 213.

183 'Une entrevue avec le Colonel Maximof'.

${ }^{184}$ Anglo-burskaya voyna 1899-1902 ... Vol 6, p. 12.

${ }^{185}$ Izedinova op. cit., p. 209.

${ }^{186}$ R Runck. Aus dem Freiheitskampfe der Buren. Die Deutschen Korps [The Boers'struggle for freedom. The German corps]. Zweibrücken: Reiselt, 1902, 209.

${ }^{187}$ D'Etchegoyen op. cit., p. 123; Pretorius, "Welcome but not that welcome ..." op. cit., p. 127. 
${ }^{188}$ Judging by a photo of the Dutch corps taken in April 1900, its members numbered 33. National Archives of South Africa, TAB, Photo 1493.

${ }^{189}$ Izedinova op. cit., p. 210; C Plokhooy. Met den mauser. Persoonlijke ervaringen in den Zuid-Afrikaanschen oorlog [With the Mauser. Personal experiences in the South African War]. Gorinchem: F Duym, 1901, 110.

${ }^{190}$ Plokhooy op. cit., p. 105. (Translated from Dutch)

${ }^{191}$ Ibid., pp. 108-109. (Translated from Dutch)

${ }^{192}$ PG Cloete. The Anglo-Boer War: A chronology. Pretoria: JP van der Walt, 2000, 136-137.

${ }^{193}$ D'Etchegoyen op. cit., pp. 188-193; Izedinova op. cit., p. 210; C Reichmann. "Extracts from the report of Capt. Carl Reichmann, Seventeenth Infantry, on operations of the Boer Army". War Department. Adjutant General's Office. Reports on military operations. South Africa and China. July, 1901. Washington, DC: Government Printing Office, 1901, 124; J van Dalsen. "Die Hollander korps tydens die Tweede Vryheidsoorlog" [The Dutch corps in the Second War for Freedom]. MA thesis. University of Pretoria, 1942, 40-42.

${ }^{194}$ Standard Encyclopaedia of Southern Africa. Vol. 5. Cape Town: Nasou, 1972, 569; MH van Meurs. "Cor van Gogh en de Boerenoorlog" [Cor van Gogh and the Boer War]. Southern Journal of Contemporary History 25/2. 2000. 193, 195.

${ }^{195}$ Lupini op. cit., pp. 159-160.

${ }^{196}$ Raoul-Duval op. cit., p. 213.

${ }^{197}$ D'Etchegoyen op. cit., pp. 129, 136; Lecoy de la Marche op. cit., p. 25.

${ }^{198}$ Macnab op. cit., p. 180; 'Une entrevue avec le Colonel Maximof'.

${ }^{199}$ Van Everdingen op. cit., p. 156. (Translated from Dutch)

${ }^{200}$ V G Shubin et al. Anglo-burskaya voyna 1899-1902 ... Vol 6, p. 12. 